\title{
Diurnal variations in plasma testosterone concentrations in the male lesser mouse lemur (Microcebus murinus)
}

\author{
M. Perret
}

Laboratoire d'Ecologie Générale, Museum National d'Histoire Naturelle, 4 avenue du petit château, F-91800 Brunoy, France

\begin{abstract}
Summary. In 6 isolated adult male lesser mouse lemurs, concentrations of testosterone in plasma were determinated at 6-h intervals over a $24-\mathrm{h}$ period. Blood samples were collected at monthly intervals and for a period of 12 months under natural photoperiod. In this nocturnal prosimian, there were no apparent diurnal changes in testosterone concentrations during the non-breeding season (autumn). During seasonal sexual activity (January-August), diurnal changes in testosterone concentrations were characterized by a significant rise during the light phase. The daily testosterone peak occurred about $8.5 \mathrm{~h}$ after sunrise from February to July, but at the beginning (January) or at the end (August) of the breeding season, the daily testosterone peak was displaced to the morning. A circannual testosterone rhythm occurred with the highest testosterone values in May/June and the lowest values 6 months later. The dramatic fall in testosterone concentrations after the summer solstice may be associated with a change in the peripheral metabolism of testosterone.
\end{abstract}

\section{Introduction}

Changes in daylength are known to be an important entraining factor of reproductive functions in many vertebrate species. In primates, seasonal variations of male reproductive hormones have been described (Mendoza, Lowe, Resko \& Levine, 1978; Michael \& Zumpe, 1978; Beck \& Wuttke, 1979; Nigi, Tiba, Yamamoto, Floescheim \& Ohsawa, 1980; Chen, Smith, Gray \& Davidson, 1981; Bellastella et al., 1983), but few studies deal with the influence of photoperiodic factors in the control of these seasonal cycles (Michael \& Bonsall, 1977; Bowers \& Elton, 1982; Wehrenberg \& Dyrenfurth, 1983). In simians, the role of daylight is unclear, probably because social factors override it. By contrast, in captive Malagasy prosimians, especially in the lesser mouse lemur, seasonal variations in body weight, in locomotor activity, in food intake, in marking behaviours and in endocrine functions have been reported and are closely photoperiod-dependent (PetterRousseaux, 1974, 1980; Van Horn \& Resko, 1977; Petter-Rousseaux \& Hladik, 1980; Perret, 1980; Schilling, 1980; Perret \& Predine, 1984). In Madagascar, the lesser mouse lemur breeds from October to March (spring and summer in the southern hemisphere) and from March to August in the natural photoperiod of Paris. In males, plasma testosterone concentrations vary from $5 \mathrm{ng} / \mathrm{ml}$ during the autumn to $50-70 \mathrm{ng} / \mathrm{ml}$ during the breeding season (Petter-Rousseaux \& Picon, 1981). This pattern of sexual activity persists when 3- or 6-month photoperiodic rhythms are imposed (Petter-Rousseaux, 1972, 1975).

A knowledge of circadian rhythms is required because it has been postulated that daily rhythms are involved in photoperiodic mechanisms (Gwinner, 1973; Meier, 1976; Beck \& Wuttke, 1979). Diurnal rhythms in peripheral testosterone concentrations have been described for a number of primate species (Macaca: Goodman, Hotchkiss, Karsch \& Knobil, 1974; Rose, Gordon \& Bernstein, 1978; Enomoto, 1980; Chambers \& Phoenix, 1981; Plant, 1982; Bernstein, Gordon \& Rose, 1983; Papio: Bielert, Howard-Tripp \& Van der Walt, 1978; Cercopithecus: Beattie \& Bulloçk 
1978; Aotus: Dixson \& Gardner, 1981; prosimians: Van Horn, Beamer \& Dixson, 1976; man: Reinberg \& Lagoguey, 1978). For simian species, it is generally assumed that testosterone concentrations increase in the evening or at night and decrease during the light phase. In contrast to simians, most species of which are active during the day, many prosimians are active at night. Dixson \& Gardner (1981) reported that testosterone concentrations in owl monkeys were lower during the night than in the day, but no significant diurnal variations of testosterone were found in galagos (Van Horn et al., 1976).

The present paper investigates the diurnal variations in plasma testosterone concentrations of the lesser mouse lemur, a nocturnal prosimian.

\section{Materials and Methods}

Animals. Six adult male lesser mouse lemurs (Microcebus murinus) were used. They were born in captivity at the Laboratory of Ecology (M.N.H.N., Brunoy, France) and were 3-4 years old. To avoid the influence of social factors (Perret, 1980; Schilling, Perret \& Predine, 1984), the animals were caged singly. The lighting was the natural photoperiod in Paris, i.e. winter solstice 21 December ( $8 \mathrm{~h}$ light $/ 16 \mathrm{~h}$ darkness $)$ and summer solstice 21 June $(16 \mathrm{~h} \mathrm{light} / 8 \mathrm{~h}$ darkness $)$. The other conditions of captivity were constant with respect to temperature $\left(20-24^{\circ} \mathrm{C}\right)$ and relative humidity (40-60\%). Throughout the year, animals were fed ad libitum with fresh fruits, eggs, milk and insects.

Because the lesser mouse lemur is a very small animal (the body length does not exceed $15 \mathrm{~cm}$ and the body weight is about $100 \mathrm{~g}$ ), blood collections were limited to 4 samples each day, taken at $03: 30,09: 30,15: 30$ and $21: 30 \mathrm{~h}$. When the daylength was greater than $15 \mathrm{~h} /$ day, during May, June and July, collections were made $30 \mathrm{~min}$ later. On the 21 st day of each month, blood samples $(\sim 60 \mu 1$ each) were collected by saphenous venepuncture within $5 \mathrm{~min}$ of removing the animal from its nestbox. During the day, the animals were sleeping in their nest-box and during the night the animals took refuge in their nest-box when briefly illuminated with a flashlight. Under these conditions the light-dark cycle was not disrupted. After centrifugation, plasma was stored at $-20^{\circ} \mathrm{C}$ until assayed.

Radioimmunoassay. Testosterone concentrations were measured in samples of $20 \mu \mathrm{l}$ plasma by the radioimmunoassay procedure given by Schilling et al. (1984). After extraction, radioimmunoassay was performed on 2 samples corresponding to 1.6 and $8 \mu$ l plasma. The antiserum was raised from 15-carboxymethyl-testosterone coupled to bovine serum albumin (purchased from Pasteur Institut, France) and was diluted 1:200000. The percentages of cross-reactivity were: testosterone $100 \%$, dihydrotestosterone $36 \%$, dihydroandrosterone $3 \%$, $\Delta^{4}$ androstenedione $1.5 \%$, other steroids $1 \%$. The intra- and interassay coefficients of variation were $14 \%$; the sensitivity was $10 \mathrm{pg}$ and the minimum detectable concentration in plasma was $0.6 \mathrm{ng} / \mathrm{ml}$. Testosterone in plasma was measured with or without chromatography on Celite:ethylene glycol columns. Testosterone was eluted with iso-octane:ethylacetate $(80: 20 \mathrm{v} / \mathrm{v})$. The coefficient of variation between chromatographed and non-chromatographed samples was $18 \%$ showing that this method is specific for testosterone. $\left[{ }^{3} \mathrm{H}\right]$ Testosterone (sp. act. $94 \mathrm{Ci} / \mathrm{nmol}$ ) was purchased from Amersham International plc, U.K., and non-radioactive steroid from Sigma, St Louis, MO, U.S.A.

Statistical analysis. All values are indicated as means \pm s.d. Statistical differences were tested using variance analysis.

\section{Results}

A single factor analysis of variance for repeated measures revealed significant differences (from $P<0.05$ to $P<0.01$ ) in testosterone concentrations at 6 -h intervals for all months except during 

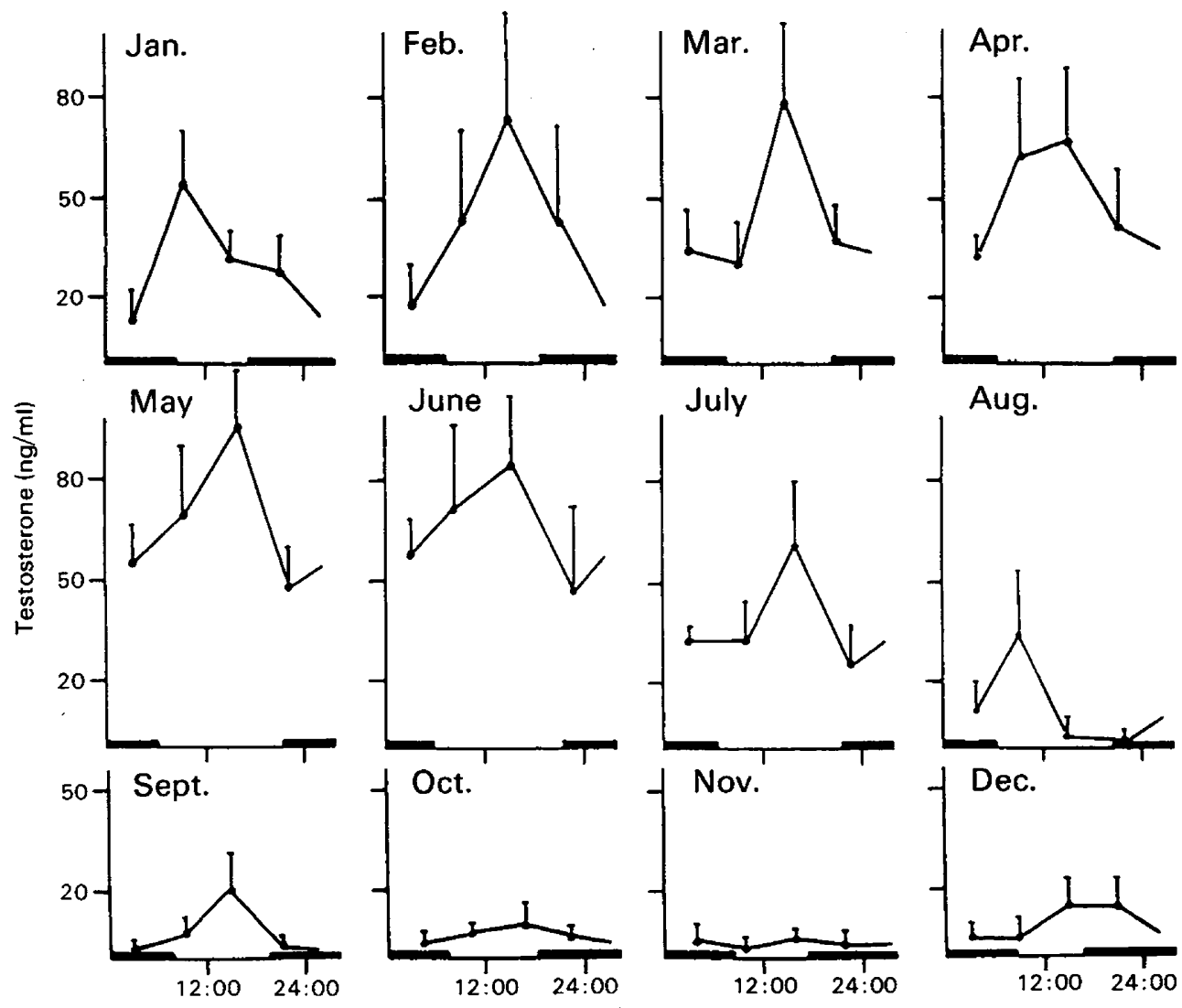

Aug.

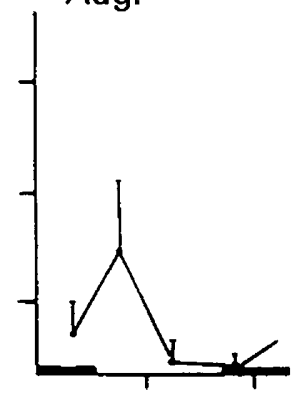

Text-fig. 1. Daily changes in plasma testosterone concentrations in mouse lemurs sampled at 6-h intervals over a 24-h period, every month. Values are mean \pm s.d. for 6 males.

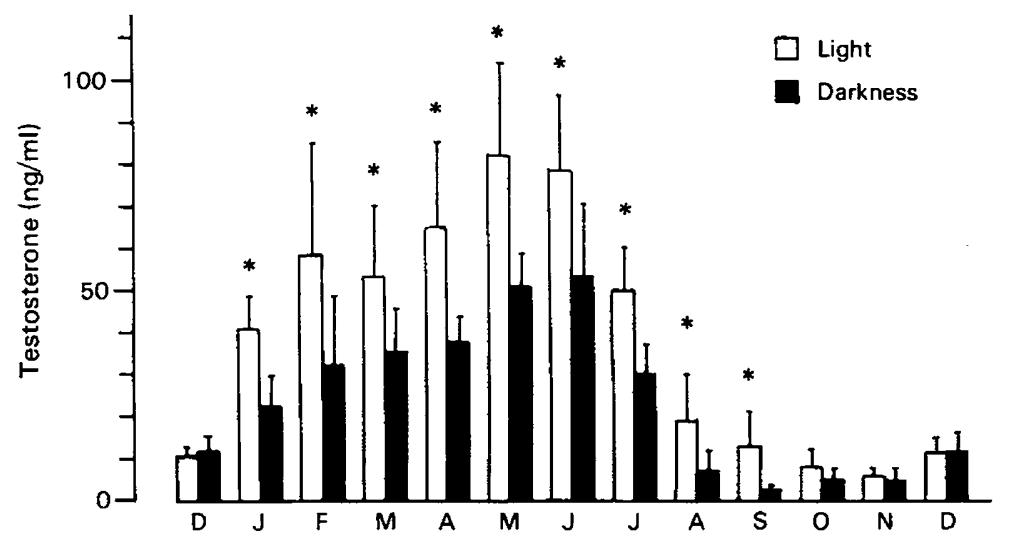

Text-fig. 2. Light-darkness differences in testosterone concentrations (mean \pm s.d. for 6 animals) in mouse lemurs throughout the year. Significant differences were recorded from January to September $\left({ }^{*} P<0.01\right)$. 
the sexual rest period: October, November and December. Changes in testosterone concentrations were associated with the increase in photoperiod (Text-fig. 1) and, from January to September, the mean concentration of nocturnal samples was significantly lower than the mean for diurnal samples (Text-fig. 2). In general, during the period of sexual activity, the mean levels recorded during daylight were reduced to about $40 \%$ in the night. This decrease was more pronounced in the transition phases at the start of sexual activity in January $(52.6 \%)$, at the end of sexual activity in August $(64 \cdot 7 \%)$ and in September $(86 \cdot 6 \%)$.

\section{Annual changes}

When the changes in the 24-h mean concentrations were expressed as a percentage of the annual individual means (Text-fig. 3), the curve appeared to be a sine function with a peak located in May/June, when the daylength was longest, and a minimum 6 months later $(P<0.001)$. Testosterone concentrations varied from $5.5 \pm 1.6 \mathrm{ng} / \mathrm{ml}$ during the rest period to $65.9 \pm 12.6$ $\mathrm{ng} / \mathrm{ml}$ near the summer solstice.

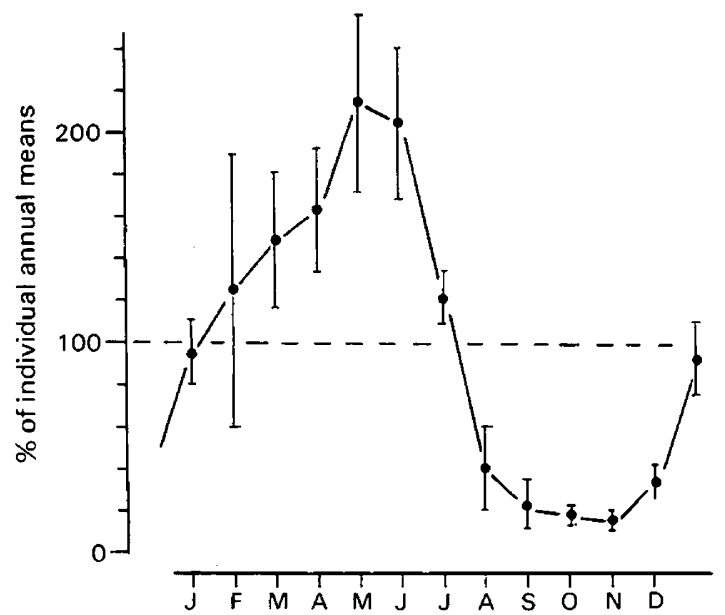

Text-fig. 3. Circannual changes in plasma testosterone concentrations. The 24-h-adjusted means are expressed as percentage of the individual annual mean $( \pm$ s.d.). The broken line represents the annual mean equal to $31.7 \pm 3.4 \mathrm{ng} / \mathrm{ml}(\mathrm{N}=6$ animals $)$.

\section{Diurnal changes}

The highest daily testosterone concentration, always significantly different from the lowest daily concentration $(P<0.01)$, occurred in the morning during January and August, and in the afternoon during the other months of the breeding season (Text-fig. 4a). Because samples were collected only 4 times a day, it was not possible to define accurately the time of the daily peak. Nevertheless, from the graphic representation of the percentage variations of daily individual means, the period when the percentage was equal to or higher than $120 \%$ was estimated. From February to July, such values occurred, on average, $6 \mathrm{~h}$ after the sunrise and lasted $6.5 \pm 1 \mathrm{~h}$ (Textfig. 4b), and the mid-period occurred $8.5 \pm 1 \mathrm{~h}$ after the sunrise. In January and August (beginning or end of seasonal sexual activity) the $120 \%$ calculated values also lasted $6.5 \mathrm{~h}$ but started about $1.5 \mathrm{~h}$ before sunrise and the mid-period occurred in the morning (Text-fig. 4b).

The amplitude of daily changes was defined as equal to half the variation between maximum and minimum testosterone concentrations within a day; it remained nearly constant throughout the period of sexual activity $(27 \cdot 5 \pm 11 \mathrm{ng} / \mathrm{ml}, \mathrm{N}=42$, from January to July) but was much lower ( $5 \cdot 5$ 


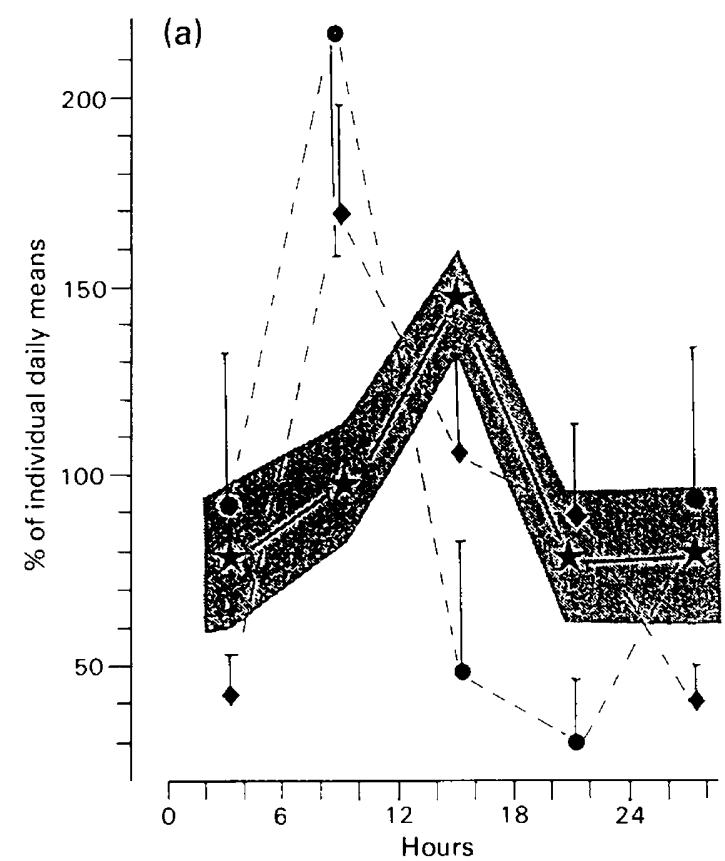

(b)
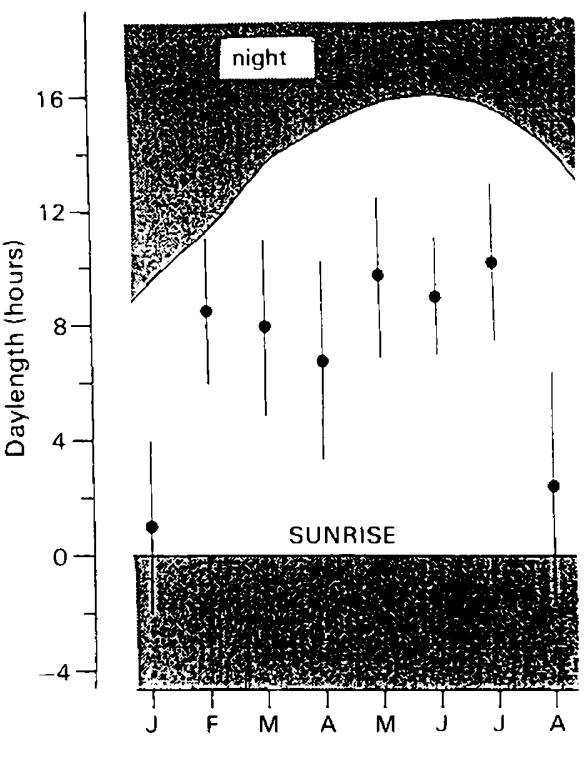

Text-fig. 4. (a) Daily changes in plasma testosterone concentrations during the sexual activity period in 6 animals. Means \pm s.d. are indicated as percentage of the daily individual mean: January $\bullet$, February to July $\star$ (s.d. is represented by the shaded area) and August 0 . (b) Testosterone daily peak defined as the period when the percentage of the individual daily mean was $\geqslant 120 \%$.

$\pm 1.4 \mathrm{ng} / \mathrm{ml}, \mathrm{N}=18$ ) in autumn. However, when amplitude was expressed as percentage variations of the daily individual means, there was a significant increase in August and in September $(P<0.01$; Text-fig. 5a). This observation could be related to annual variations in the peripheral metabolism of testosterone. Peripheral testosterone metabolism can be estimated for the lesser mouse lemur by the magnitude of the decrease for testosterone concentrations between maximal and minimal daily levels. The percentage decrease per hour of testosterone peak value varied during the breeding season (Text-fig. 5b): the highest values were encountered from May to September when minimum testosterone values occurred at the beginning of the dark period, i.e. $6 \mathrm{~h}$ after the daily peak. From January to April, the percentage decrease of testosterone was less and testosterone values reached a minimum at the end of the dark period, i.e. 18 or $12 \mathrm{~h}$ later than the daily peak. Therefore, at the beginning of the night, when lesser mouse lemurs exhibit numerous behaviours, especially sexual behaviours, the mean testosterone concentrations (Text-fig. 5b) progressively increased from January to May (increasing secretion, constant peripheral metabolism), remained constant until the time when the daylength was longest (increasing secretion, increasing peripheral metabolism), and then, although the daylength was still long, abruptly decreased in July/August (constant or decreasing secretion, increasing peripheral metabolism).

\section{Discussion}

Except during the sexual rest period (autumn), plasma testosterone levels in the lesser mouse lemur undergo significant daily changes. In this nocturnal species, the mean testosterone concentration in the night was significantly lower than the mean for samples taken in the daytime, from January to 


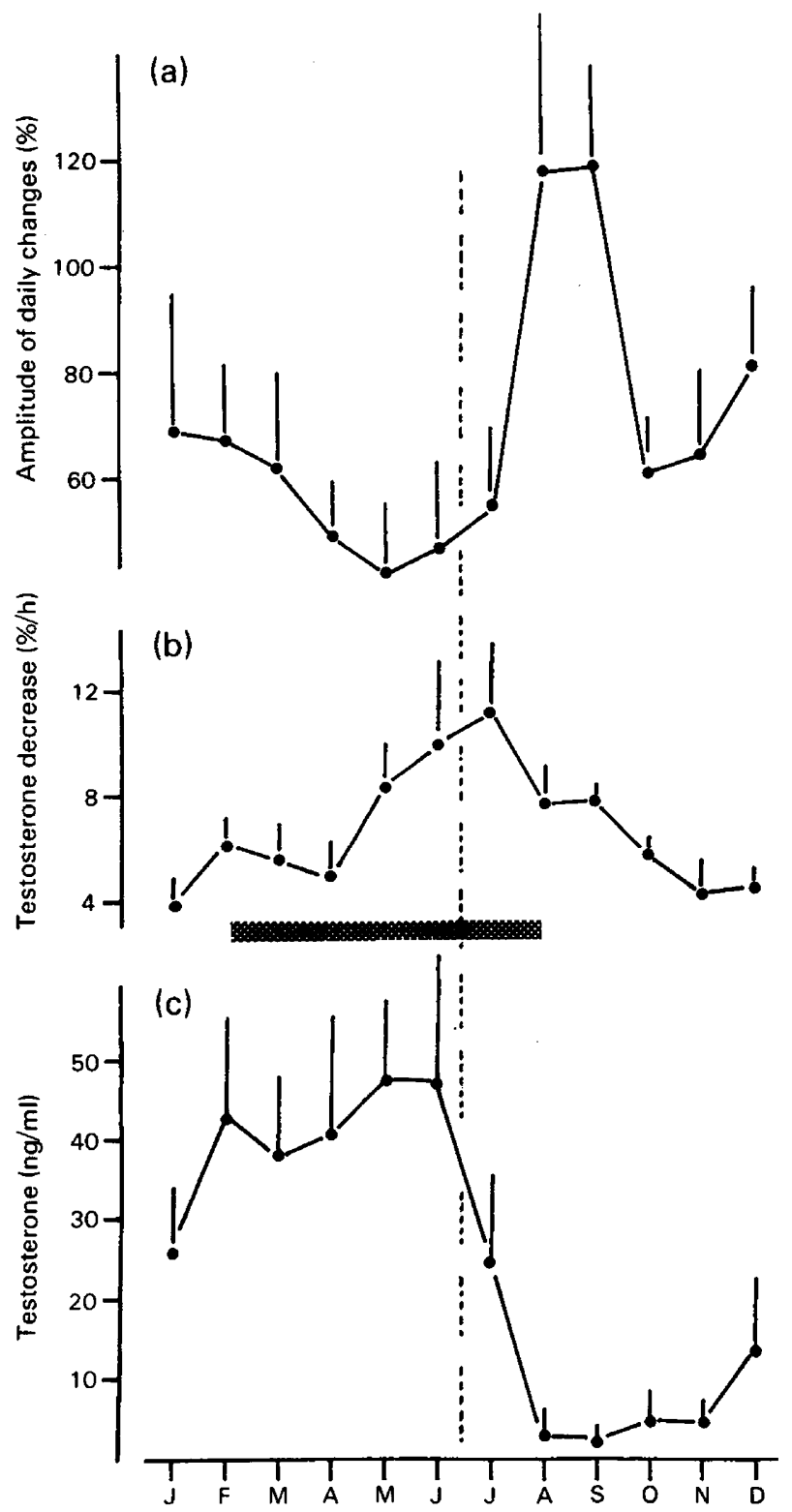

Text-fig. 5. Relationship between (a) the amplitude of daily testosterone variations, (b) the percentage decrease per hour of testosterone and (c) mean concentrations of testosterone during the first part of the night. Values are mean \pm s.d. for 6 animals. The summer solstice is indicated by a broken line and the breeding season by the grey area.

September. These daily changes were the reverse of those observed in diurnal species for which nocturnal increases in plasma testosterone levels have been reported (Goodman et al., 1974; Rose $e t$ al., 1978; Enomoto, 1980; Bielert et al., 1978; Bernstein et al., 1983) but were similar to those described for the owl monkey (Dixson \& Gardner, 1981) which is a nocturnal simian.

Nevertheless, whether the primate studied is a diurnal or nocturnal species, it appears that testosterone concentrations are always reduced during the period of activity and that the daily peak 
is recorded during sleep. In the lesser mouse lemur, during the breeding season, testosterone concentrations reached a minimum in the first part of the night, as they do in the owl monkey (Dixson \& Gardner, 1981). Lesser mouse lemurs are most active in the first part of the night as shown by records of locomotor and feeding activities and basal oxygen consumption (Chevillard, 1976; Pages \& Petter-Rousseaux, 1980) and from field observations (Martin, 1973).

Capture, handling and repeated venepuncture may be an important cause of the observed variability in the testosterone concentrations because stress leads to a fall in testosterone values (Rose et al., 1972; Coe et al., 1978; Goncharov et al., 1979; Bernstein et al., 1983). However, in our experiments, the first venepuncture took place in the morning and the highest testosterone concentrations were more often recorded in the afternoon, i.e. $6 \mathrm{~h}$ later. Furthermore, no significant changes in diurnal testosterone variations were demonstrated in macaques that were bled either every $3 \mathrm{~h}$ for $24 \mathrm{~h}$ (Goodman et al., 1974) or 5 times within $90 \mathrm{~min}$ (Rose et al., 1978). It has also been shown that the secretions from the adrenal cortex do not contribute to the diurnal fluctuations of testosterone (Michael, Setchell \& Plant, 1974; Goodman et al., 1974; Eaton \& Resko, 1974).

The relationship between diurnal and seasonal variations in plasma testosterone concentrations has been investigated for macaques (Rose et al., 1978; Enomoto, 1980) using data collected during the breeding season or during the non-mating season. The results indicated that the circadian variations were maintained in both sexual conditions and were only displaced upwards during the mating season. In the wild, as in captivity, lesser mouse lemurs breed seasonally and variations of reproductive functions are photoperiod-dependent (Petter-Rousseaux, 1972, 1975). The annual daylength variation which is about $8 \mathrm{~h}$ in the natural photoperiod in Paris, but only $2 \mathrm{~h}$ in Madagascar, affects the reproductive processes similarly (Petter-Rousseaux, 1974). Annual variations in testosterone concentrations are well documented in the lesser mouse lemur (PetterRousseaux \& Picon, 1981; Schilling et al., 1984). The present study revealed that the diurnal changes varied throughout the year. There were no diurnal changes detectable during the nonbreeding season but, during the period of sexual activity (February to July), diurnal changes in testosterone values were characterized by a daily peak in the afternoon. In the transition phases from rest to activity in January and from activity to rest in August, testosterone concentrations were highest in the morning. These variations in circadian rhythms of testosterone may be associated with seasonal changes in other hormones such as cortisol (Perret \& Predine, 1984) or thyroxine (Petter-Rousseaux, 1984). A similar seasonal displacement of the testosterone daily peak has been described for men : the circadian acrophase occurs in the early morning in May (period of relative decrease in sexual activity and testosterone levels) and in the early afternoon when sexual activity and testosterone concentrations are highest (Reinberg \& Lagoguey, 1978). Therefore, to follow long-term environmental or social influences on testosterone levels in mouse lemurs during the breeding season, it would be necessary to select a fixed time after sunrise $(8 \mathrm{~h})$ for the collection of blood samples each day, instead of the same hour of the day.

From the daily increase of testosterone concentrations, it seems possible that the peripheral metabolism of testosterone might be greater from May to September. These results agree with those found in seasonally breeding animals such as the fox (Maurel \& Boissin, 1982), the hedgehog (Saboureau, Laurent \& Boissin, 1982) or the ram (Darbeida \& Brudieux, 1980). Changes in testosterone metabolism have been related to seasonal variations of testosterone-binding protein (SBP): an inverse correlation was found between the SBP-binding capacity and the testosterone metabolic clearance rate (Maurel, 1980; Saboureau et al., 1982). Preliminary investigations on SBP binding capacity in mouse lemurs (determined by an equilibrium dialysis method) indicated that the SBP-binding capacity varied seasonally: it was significantly higher in autumn $(P<0.01)$ when testosterone concentrations were low, and reached a minimum from May to August (M. Perret, unpublished data) when the testosterone peripheral metabolism appeared to be highest.

I thank Professor J. Roffi for permission to use the technical facilities of the Laboratory of Endocrinology, University Paris XI (Orsay, France). 


\section{References}

Beattie, C.W. \& Bullock, B.C. (1978) Diurnal variation of serum androgen and estradiol-17\% in the adult male green monkey (Cercopithecus sp.). Biol. Reprod. 19, 36-39.

Beck, W. \& Wuttke, W. (1979) Annual rhythms of luteinizing hormone, follicle-stimulating hormone, prolactin and testosterone in the serum of male rhesus monkeys. J. Endocr. 83, 131-139.

Bellastella, A., Criscuolo, T., Mango, A., Perrone, L., Sinisi, A.A. \& Faggiano, R.L. (1983) Circannual rhythms of plasma luteinizing hormone, follicle stimulating hormone, testosterone, prolactin and cortisol in prepuberty. Clin. Endocr. 19, 453-459.

Bernstein, I.S., Gordon, T.P. \& Rose, R.M. (1983) The interaction of hormones, behavior and social context in non-human primates. In Hormones and Aggressive Behavior, pp. 535-561. Ed. B. B. Svare. Plenum, New York.

Bielert, C., Howard-Tripp, M.E. \& Van der Walt, L.A. (1978) Diurnal variations in serum testosterone concentrations of captive adult male chacma baboons (Papio ursinus). Am. J. Primatol. 1, 421-425.

Bowers, C.L. \& Elton, R.H. (1982) Synchronization of menstrual cycles in pigtail macaques using photoperiod. J. med. Primatol. 11, 252-256.

Chambers, K.C. \& Phoenix, C.H. (1981) Diurnal patterns of testosterone, dihydrotestosterone, estradiol and cortisol in serum of rhesus male: relationship to sexual behavior in aging male. Horm. Behav. 15, 416426.

Chen, J.J., Smith, E.R., Gray, G.D. \& Davidson, J.M. (1981) Seasonal changes in plasma testosterone and ejaculatory capacity in squirrel monkeys (Saimiri sciureus). Primates 22, 253-260.

Chevillard, M.C. (1976) Capacités thermorégulatrices d'un lémurien malgache, Microcebus murinus (Miller, 1777). Thèse 3ème cycle, Paris VII, 58 pp.

Coe, C.L., Mendoza, S.P., Davidson, J.M., Smith, E.R., Dallman, M.F. \& Levine, S. (1978) Hormonal response to stress in squirrel monkey (Saimiri sciureus). Neuroendocrinology 26, 367-377.

Darbeida, H. \& Brudieux, R. (1980) Seasonal variations in plasma testosterone and dihydrotestosterone and in metabolic clearance rate of testosterone in rams in Algeria. J. Reprod. Fert. 59, 229-235.

Dixson, A.F. \& Gardner, J.S. (1981) Diurnal variations in plasma testosterone in a male nocturnal primate, the owl monkey (Aotus trivirgatus). J. Reprod. Fert. 62, 83-86.

Eaton, G.G. \& Resko, J.A. (1974) Plasma testosterone and male dominance in a japanese macaque ( $\mathrm{Macaca}$ fuscata) troop compared with repeated measures of testosterone in laboratory males. Horm. Behav. 5, 251-259.

Enomoto, T. (1980) Diurnal variations in plasma testosterone and cortisol in the male japanese monkey. J. Anthrop. Soc. Japan 88, 285-287.

Goncharov, N.P., Taranov, A.G., Antonichev, A.V., Gorlushkin, V.M., Cezan, S.Z. \& Diczfaluzy, S. (1979) Effect of stress on the profile of plasma steroids in baboons (Papio hamadryas). Acta endocr., Copenh. 90, 372-384.
Goodman, R.L., Hotchkiss, J., Karsch, F.J. \& Knobil, E. (1974) Diurnal variations in serum testosterone concentrations in the adult male rhesus monkey. Biol. Reprod. 11, 624-630.

Gwinner, E. (1973) Circannual rhythms in birds: their interaction with circadian rhythms and environmental photoperiod. J. Reprod. Fert., Suppl. 19, 5165.

Martin, R.D. (1973) A review of the behaviour and ecology of the lesser mouse lemur (Microcebus murinus, Miller, 1777). In Ecology and Behaviour of Primates, pp. 1-66. Eds R. P. Michael \& J. H. Crook. Academic Press, New York.

Maurel, E. (1980) Etude de la capacité de liaison de la proteine plasmatique liant la testostérone chez deux mammifères sauvages à activité cyclique, le renard et le blaireau. C. r. hebd. Séanc. Acad. Sci. Paris, D 291, 693-696.

Maurel, E. \& Boissin, J. (1982) Métabolisme périphérique de la testostérone en relation avec le cycle annuel de la testostérone et de la $5 \alpha$ diOH-testostérone plasmatiques chez le blaireau européen (Meles meles) et le renard roux (Vulpes vulpes). Can. J. Zool. 60, 406-416.

Meier, A.H. (1976) Chronoendocrinology of the whitethroated sparrow. In Proc. 16th Int. Ornith. Congr. pp. 355-364. Eds M. J. Frith \& J. H. Calaby. Griffin Press, Australia.

Mendoza, S.P., Lowe, E.L., Resko, J.A. \& Levine, S. (1978) Seasonal variations in gonadal hormones and social behavior in squirrel monkeys. Physiol. Behav. 20, 515-522.

Michael, R.P. \& Bonsall, R.W. (1977) A 3-year study of an annual rhythm in plasma androgen levels in male rhesus monkeys (Macaca mulatta) in a constant laboratory environment. J. Reprod. Fert. 49, 129-131.

Michael, R.P. \& Zumpe, D. (1978) Annual cycles of aggression and plasma testosterone in captive male rhesus monkeys. Psychoneuroendocrinology 3, 217220.

Michael, R.P., Setchell, K.D. \& Plant, T.M. (1974) Diurnal changes in plasma testosterone and studies on plasma corticosteroid in non-anaesthetized male rhesus monkeys (Macaca mulatta). J. Endocr. 63, 325-335.

Nigi, H., Tiba, T., Yamamoto, S., Floescheim, Y. \& Ohsawa, N. (1980) Sexual maturation and seasonal changes in reproductive phenomena of male japanese monkeys (Macaca fuscata) at Takasakiyama. Primates 21, 230-240.

Pages, E. \& Petter-Rousseaux, A. (1980) Annual variations in the circadian activity rhythms of five sympatric species of nocturnal prosimians in captivity. In Nocturnal Malagasy Primates. Ecology, Physiology and Behavior, pp. 153-163. Eds P. CharlesDominique, H. M. Cooper, A. Hladik, C. M. Hladik, E. Pages, G. F. Pariente, A. Petter-Rousseaux, J. J. Petter \& A. Schilling. Academic Press, New York.

Perret, M. (1980) Influence de la captivité et du groupement social sur la physiologie du microcèbe (Microcebus murinus, Cheirogaleinae, Primates). Thèse Doctorat d'Etat, Université Paris IX, $350 \mathrm{pp}$. 
Perret, M. \& Predine, J. (1984) Influence of long-term grouping in serum cortisol levels in Microcebus murinus (Prosimii). Horm. Behav. 18, 346-358.

Petter-Rousseaux, A. (1972) Application d'un système semestriel de variation de la photopériode chez Microcebus murinus. Annls Biol. anim. Biochim. Biophys. 12, 367-375.

Petter-Rousseaux, A. (1974) Photoperiod, sexual activity and body weight variations of Microcebus murinus (Miller 1777). In Prosimian Biology, pp. 365-373. Eds R. D. Martin, G. A. Doyle \& A. C. Walker. Duckworth, London.

Petter-Rousseaux, A. (1975) Activité sexuelle de Microcebus murinus soumis à des régimes photopériodiques expérimentaux. Annls Biol. anim. Biochim. Biophys. $15,503-508$.

Petter-Rousseaux, A. (1980) Seasonal activity rhythms, reproduction and body weight variations in 5 sympatric nocturnal prosimians in simulated light and climatic conditions. In Nocturnal Malagasy Primates. Ecology, Physiology and Behavior, pp. 137152. Eds P. Charles-Dominique, H. M. Cooper, A. Hladik, C. M. Hladik, E. Pages, G. F. Pariente, A. Petter-Rousseaux, J. J. Petter \& A. Schilling. Academic Press, New York.

Petter-Rousseaux, A. (1984) Annual variations in the plasma thyroxine level in Microcebus murinus. Gen. comp. Endocr. 55, 405-409.

Petter-Rousseaux, A. \& Hladik, C.M. (1980) A comparative study of food intake in 5 nocturnal prosimians in simulated conditions. In Nocturnal Malagasy Primates. Ecology, Physiology and Behavior, pp. 153-169. Eds P. Charles-Dominique, H. M. Cooper, A. Hladik, C. M. Hladik, E. Pages, A. Petter-Rousseaux, J. J. Petter \& A. Schilling. Academic Press, New York.

Petter-Rousseaux, A. \& Picon, R. (1981) Annual variation in the plasma testosterone in Microcebus murinus. Folia Primatol. 36, 183-190.

Plant, T.M. (1982) A striking diurnal variation in plasma testosterone concentrations in infantile male rhesus monkeys (Macaca mulatta). Neuroendocrinology 35, 370-373.
Reinberg, A. \& Lagoguey, M. (1978) Circadian and circannual rhythms in the sexual activity and in plasma hormones (FSH-LH, testosterone) of 5 young healthy parisian males. Archs Sex. Behav. 7, 1330.

Rose, R.M., Gordon, T.P. \& Bernstein, I.S. (1972) Plasma testosterone levels in the male rhesus: influences of sexual and social stimuli. Science, N.Y. 78, 643645.

Rose, R.M., Gordon, T.P. \& Bernstein, I.S. (1978) Diurnal variation in plasma testosterone and cortisol in rhesus monkeys living in social groups. J. Endocr. 76, 67-74.

Saboureau, M., Laurent, A.M. \& Boissin, J. (1982) Plasma testosterone binding capacity in relation to the annual testicular cycle in an hibernating mammal, the hedgehog (Erinaceus europaeus). Gen. comp. Endocr. 47, 53-63.

Schilling, A. (1980) Seasonal variation in the fecal marking of Cheirogaleus medius in simulated climatic conditions. In Nocturnal Malagasy Primates. Ecology, Physiology and Behavior, pp. 180-190. Eds P. CharlesDominique, H. M. Cooper, A. Hladik, C. M. Hladik, E. Pages, G. F. Pariente, A. Petter-Rousseaux, J. J. Petter \& A. Schilling. Academic Press, New York.

Schilling, A., Perret, M. \& Predine, J. (1984) Sexual inhibition in a prosimian primate: a pheromone-like effect. J. Endocr. 102, 148-151.

Van Horn, R.N. \& Resko, J.A. (1977) The reproductive cycle of the ring-tailed lemur (Lemur catta), sex steroid levels and sexual receptivity under controlled photoperiods. Endocrinology 101, 1579-1586.

Van Horn, R.N., Beamer, N.B. \& Dixson, A.F. (1976) Diurnal variations of plasma testosterone in two prosimian primates (Galago crassicaudatus crassicaudatus and Lemur catta). Biol. Reprod. 15, 523-528.

Wehrenberg, W.B. \& Dyrenfurth, I. (1983) Photoperiod and ovulatory menstrual cycles in female macaque monkeys. J. Reprod. Fert. 68, 119-122.

Received 12 September 1984 